\title{
PARTICIPATORY RURAL PLANNING AND LOCAL CAPABILITIES TOWARD OFFERING NATURE TOURISM
}

\author{
ALMA R. BOJORQUEZ-VARGAS ${ }^{1}$, ROMANO G. SEGRADO PAVON ${ }^{2}$ \& MARÍA DENY D. POOT QUINTAL ${ }^{2}$ \\ ${ }^{1}$ Universidad Autónoma de San Luis Potosi, Mexico \\ ${ }^{2}$ Universidad de Quintana Roo, Mexico
}

\begin{abstract}
In this study, ecotourism alternatives were identified that could complement the tourism offer in ejido Los Sabinos Numero Dos; which is a rural community located in the area of influence of the Biosphere Reserve-Sierra del Abra Tanchipa; this reserve is located in the Huasteca region of the state of San Luis Potosí, Mexico. The methodology carried out consisted of a participatory rural planning. Prior to that, a training workshop course was given for members of this ejido on conceptual issues and origins on nature tourism, sustainable development and the importance of land use planning. The participatory rural technique applied was participatory mapping for the identification of tourism resources with exploitation potential. The ejido members shared their learning and opportunities to open new activities as a new offer of nature tourism. As a result, new initiatives were identified in the form of local sustainable companies based on the potential to expand the tourism offer and allow greater benefits and interests of ejidatarios. It was found that the training course offered criticism, debates and reflections on the potential of its natural and cultural resources for tourism use. Likewise, participatory mapping led ejidatarios to share knowledge, analyse the location of interesting resources for tourism, their current conditions and the identification of new projects to expand the tourism offer.

Keywords: sustainable tourism, Sierra del Abra Tanchipa, community development, participatory Cartography, Huasteca Potosina.
\end{abstract}

\section{INTRODUCTION}

Among some data, the entry of foreign currency in Mexico by international travellers amounted to 1,941 million dollars, at the beginning of the year 2018 which represents an increase of $0.7 \%$ compared to the beginning of the year 2017 [1]. Regarding the number of tourists who entered the country at the beginning of 2018, it was 3.4 million; higher figure in 379 thousand tourists compared to the beginning of 2017, which means an annual increase of $12.7 \%$ [1]. The World Tourism Organization - UNWTO [2] indicated at the end of 2018 to Mexico as the sixth place in arrival of tourists, with the figure of 39.3 million foreign tourists, after France, Spain, United States, China and Italy in ascending order [2].

\subsection{Increasing tourism in Huasteca Potosina region}

This increase is encouraging but it also means a challenge of preparation, because it is not about increasing the tourist influx without taking into account adequate planning in infrastructure, training, service quality, much less, without the anticipation of social impacts and environmental that charge high bill to the natural and cultural heritage of the destinations.

The challenge is also reflected at the state level San Luis Potosí (SLP), and its constant growth of the estimated tourist influx of 7\% per year in Huasteca Potosina region [3]. The arrival of visitors is constant most of the year, sharpening during Holy Week, summer vacations, festivities of the Dead (locally known as Xantolo Celebration) and, Christmas and New Year holidays.

The problem is suffered by both, local residents and tourists, who fail to fully satisfy their experience, given the great congestion of the most popular destinations. The director of Destination Management of the SECTUR of the last federal government period, said 
"problems of overloading by volume of tourists have begun to occur, especially in high seasons [...], which jeopardizes its viability as a tourist destination", and He mentioned Xilitla, a municipality of San Luis Potosi State, as one of the five most visible and worrisome in the country [4].

What about countless natural and cultural resources with scenic beauty that could alternate the limited tourist offer currently, and in turn, distribute the mass of visitors? Entering the tourist activity is of interest to various locations, especially those with limited options in sources of economic income. The Huasteca region in San Luis Potosi has a wide variety of options that, if studied its tourist potential, could alternate the current tourist offer, since it has a diversity of sites with valuable natural, ethnic and archaeological heritage.

\subsection{Ecotourism in the area of influence of the RBSAT}

This document presents such concern, which allowed us to investigate the nature tourism alternatives around the Sierra del Abra Tanchipa Biosphere Reserve (RBSAT), located in the Municipalities of Tamuin and Ciudad Valles; the latter, as the main place of tourism companies in the region, such as hotels, restaurants and adventure tour operators.

Little more than ten years ago that the Los Sabinos Numero Dos ejido (Los Sabinos), located in the Influence Zone of the RBSAT (Fig. 1), has been driven in the activity of adventure and nature tourism, specifically, the use of an attractive natural underground cavity which impresses visitors by the formations of the speleothems inside. This cave, known as Las Grutas de Los Sabinos (Sabinos Grottoes) located in the ejido with the same name, had a certain boost with financial and training support from municipal governments between 2005 and 2009 [5] and despite this, and being located just $13 \mathrm{~km}$ from the city, it does not achieve significant benefits to detonate as a recipient of a significant number of visitors a year.

The RBSAT was declared a protected natural area on June 6, 1994 by the federal government as a presidential decree. In this reserve, a large area of sub deciduous jungle is protected, which are still in good condition. In addition, it is the little altered habitat of an important diversity of threatened flora and fauna and some declared endangered [6]. These extensions of protected forests make their ecosystems with biological diversity acquire recognition as a valuable natural heritage, not only regional, but national. Among the most prominent species are the jaguar (Panthera onca), the tiger or locally called tigrillo (Leopardus Wiedii) the green macaw (Ara militaris), the tamaulipeco parrot (Amazona viridigenalis), the chamal (Dioon edule), in danger of extinction and the palm soyate (Beaucarnea inermis) as a threatened species [7].

The polygon of the natural area protected (ANP) measures 21,464.44 ha and of that, almost $80 \%$ corresponds to the property of three ejidos (kind of collective land property in Mexico): ejido Las Palmas, Los Sabinos Numero Dos and el ejido Laguna del Mante; this last one mentioned occupies $15,737.68$ ha [6]. On the other hand, only 425 correspond to ejido Los Sabinos Numero Dos; and despite this small space in the reserve, it is the ejido that has ventured into the tourist use of the RBSAT's area of influence, due to the grottoes.

The purpose of this study was to apply participatory mapping tools to identify touristic alternatives in the ejido Los Sabinos Numero Dos, as a complement to the current tourist offer, since it only has tourism in the Grottos. Also, that alternatives should be low environmental impact, since it is located in the area of influence of the nature reserve. Therefore, local training on sustainability and nature tourism were both key elements in this study. 


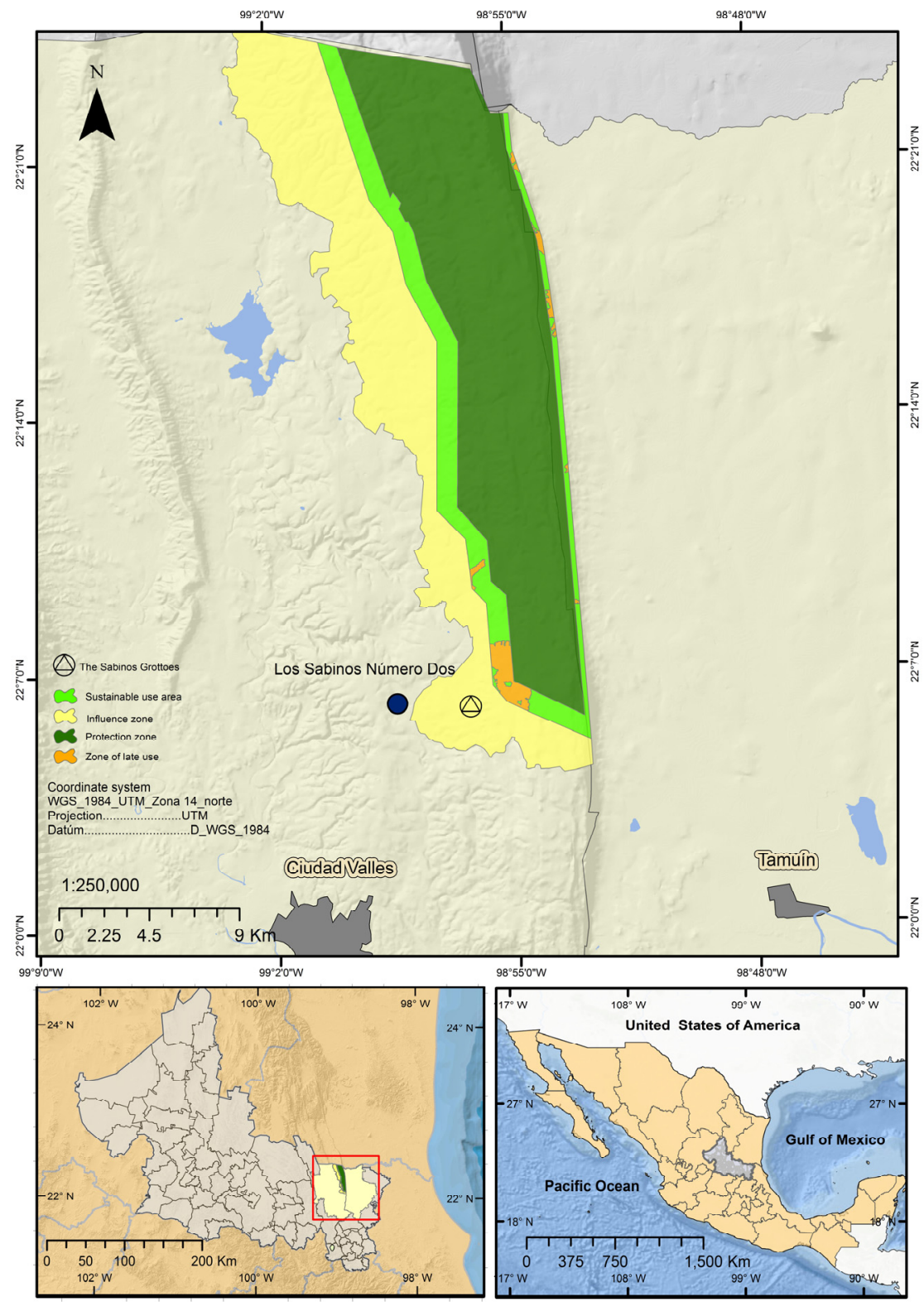

Figure 1: Location of the Los Sabinos RBSAT. (Source: Bojórquez-Vargas et al. 2013 [5].)

\subsection{The Sabinos Grottoes}

The type of soil and the geological characteristics of the area of influence of the RBSAT, offers underground cracks and narrow basements difficult to penetrate for the spelunking activity, also in the ejido Laguna del Mante, however, in the ejido there is a vertical cave called 


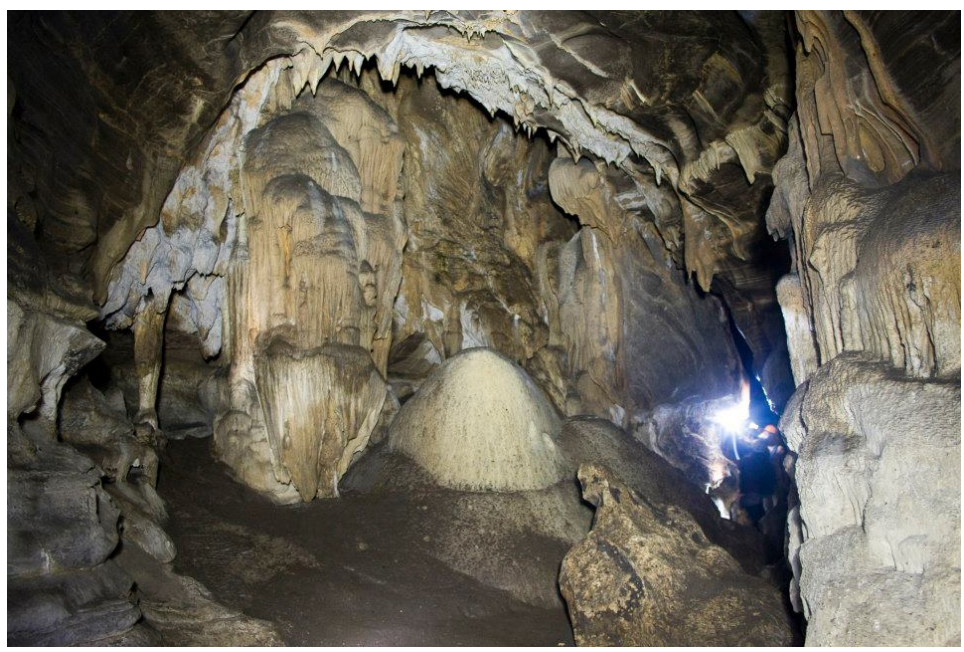

Figure 2: Inside the grottoes Los Sabinos.

Sotano del Arroyo that can be explorable, but definitely for better accessibility, the main tourist attraction is where the caves known as the Grotto of Los Sabinos are located (Fig. 2).

\section{THEORETICAL FRAMEWORK}

The World Tourism Organization (UNWTO) defines sustainable tourism as "Tourism that takes full account of its current and future economic, social and environmental impacts, addressing the needs of visitors, the industry, the environment and host communities" [8].

Chung-Shing, Hoi \& Lawal, based on many literature references, define nature tourism as “...that is based on direct enjoyment and observation of some relatively undisturbed phenomenon of nature or a range of nature dependent experiences with low environmental impact, labour intensive activities, and social and economical contributions" [9]. For this reason, seeking a balance between the social, economic and environmental dimensions is where tourism activity becomes sustainable.

In Mexico, nature tourism or ecotourism is strongly related to local communities, natural environments, conservation and proper planning and management. Therefore, "to qualify a tourism activity as ecotourism, it should participate and benefit the local communities, protect the natural ecosystem, follow sound planning and management, as well as target a group of tourists whose motives and behaviours are distinct from conventional tourists" [10].

When the development processes for a rural community or group are exogenously designed, local involvement in that development process is unlikely. That is, without interest, knowledge, or without active participation of one rural population, a local involvement in that development process is unlikely because it is usually considered from experts outside the community. This has been known for decades, however, the inertia of the alienated processes, decisions from outside, has touched many rural communities, one is the ejido Los Sabinos Numero Dos.

\subsection{Participation in development processes}

This is stated by Arnistein, quoted by Guillen et al. [11] when he argues that "citizen participation, when it is not pure cosmetic, is citizen power". Therefore, increasing 
participation implies redistributing power. For Arnestein, the ladder of participation classified the degree of the same as eight steps of an imaginary ladder in which the first steps consisted of non-participation, the pieces of the part of the ladder indicate a symbolic participation, while that the last rungs single out the true citizen power [11].

To achieve a participation and involvement of the local population in the development processes, that is, that participation of citizen power mentioned by Arnestein, where the self-management of the population is achieved, the process is supported by accompaniments based on methodologies and research techniques with participatory approaches, the facilitation or accompaniment of technicians or researchers will also not be without the consent of the same population.

It is then that, through community or local participation and focused on increasing their capabilities, when the process of empowerment of a community or a group of citizens is genuinely managed, community-based actions emerge from the bottom up. Only from top to bottom will scientists, researchers and the government be there to support and facilitate access to sustainable livelihoods and means of protection. Both stakeholder groups must also share knowledge [12]. However, many scientists and government officials often underestimate if they do not rule out, the value of local knowledge and community activities [12].

In that sense, Chapman and Kirk [13] argue that community participation is the mechanism for active community involvement in partnership working, decision making and representation in community structures. As Aref asserts "Without participation, there is obviously no partnership, no development and no program" [14]. The author also quotes to Miranda saying that "community participation rises the sense of control on the people over subjects that touch their lives and also promotes self-confidence and self-awareness". In that sense, is important to enable community members to become actively involved and to take responsibility for their own development and step by step improving their decision-making power [14], [15].

\subsection{Social participatory mapping.}

To begin, Osorio Campillo and Sánchez [16] define the cartography as:

"Elaboration of a map with various routes, lines, paths and paths fed from perceptions, events, knowledge, places of passage, images and conversations, which indicate the uniqueness of a territory. These paths are only readable on the map, oriented towards an experimentation that acts on the real".

These authors also quote to Alberich-Nistal when he says that the social map works as a tool that "allows us to see the relationships in the social network, in a more complete, complex and close to reality mesh, including hierarchical relationships or at different levels and also, the relationships between different networks" [16].

In congruence with the authors, the tool in principle is only descriptive but very useful for conducting participatory diagnoses on social networks; propose changes, new sets of action, develop possible scenarios, put yourself in a position of future of how you can work to change current relationships [16].

John Pickles, quoted by Perkins [17] acknowledged that:

"It is quite well established in critical studies (if not in practice) that the cartographic anguish of universalist modernist cartography has been practically suspended. Instead, there is a much more nuanced and multiform understanding of the practice and use of cartography, and in which the production of geographical images is understood as a completely social product". 
However, it continues to be discussed and is continually divided between critical studies and the hegemonic practice of scientific mapping worldwide [17].

A wide variety of forms of participatory mapping have been used. To mention a few, Cadag and Gaillard [12] mention as examples: terrain mapping, "stone mapping", sketch mapping, 2D scale mapping, GPS mapping and Geographic Information System (GIS) mapping Web based and interoperable; These are mentioned from the simplest to the most demanding in terms of resources. However, the least demanding and most accessible types of mapping (land and stone mapping) are often rejected as a cartographic technique because of the lack of credibility.

On the contrary, very sophisticated GPS and web-based GIS mapping require training and huge resources; In spite of this, they do not guarantee total credibility, since they can also be manipulated by people outside the community, despite being credible to government officials and scientists. On average, drawing sketch maps is a form of participatory mapping that is most frequently used, for example, for disaster risk reduction. However, since sketch maps are not scaled or georeferenced, they are often discarded by government officials and scientists [12].

\section{RESEARCH METHOD}

For this research, which aims to identify alternatives to expand the current tourism offer in ejido Los Sabinos Numero Dos, in congruence with activities of low environmental impact, a participatory methodology was chosen, since they are local residents and local stakeholders in this activity who know better the tourist resources they have. However, participants were required to acquire greater knowledge about the trends of nature tourism and the segments and activities in which they are classified.

To meet this need, before conducting the participatory mapping, a 16-hour workshop course was given to a group of the local population in August 2018, consisting of ejidatarios (people who belong to the ejido), ejidatarios' children and local residents; who responded to the invitation stating that they were interested in venturing into the tourist activity.

The workshop course was held at the premises of the ejido house of Los Sabinos. The topics to be addressed and the time of the workshop course and what it would consist of were presented for consideration. Based on an agreement, the duration of the workshop course and the subjects of the same course were established in Table 1 as follows:

Table 1: Content of the topics to be developed in the Workshop Course.

\begin{tabular}{|ll|}
\hline \multicolumn{1}{|c|}{ Workshop topics } \\
\hline Topic 1. & What is tourism? \\
\hline Topic 2. & Sustainable development \\
\hline Topic 3. & Sustainable tourism \\
\hline Topic 4. & Nature tourism \\
\hline Topic 4.1. & Ecotourism \\
\hline Topic 4.2. Adventure tourism \\
\hline Topic 4.3. Rural tourism \\
\hline Topic 5. & Community tourism \\
\hline Topic 6. & Importance of territorial planning \\
\hline
\end{tabular}

The topics were addressed using slides, reflection time and peer discussion and with the support of a printed manual for each participant, in which the workshop course content was 
developed in detail and with drawings and images and examples. Once the group of participants became familiar with the concepts, terms on sustainable tourism and the classification of activities in which nature tourism consists, the mapping was made up of work teams, with the active participation of ejidatarios and the facilitation of researchers.

\section{RESULTS}

In order to apply the knowledge acquired from the workshop course previously taught, the participants worked in small teams to trace the ejido territory and identify the tourist resources they consider to be exploited as nature tourism. To do this, flipchart papers, colourful markers and the guide of the printed course manual were used.

\subsection{Organization of equipment for mapping participation}

Some teams focused on identifying resources or activities with tourism potential in the ecotourism modality, others in the adventure tourism modality and others in the nature tourism modality. The facilitation of the team of researchers was conducted by guiding questions (Table 2).

Table 2: Guide for facilitation in participatory mapping. (Source: authors'own.)

\begin{tabular}{|l|}
\hline 1. Wuiding Questions \\
\hline 1.1. What is needed (training, infrastructure, equipment) for its use? \\
\hline 1.2. In what period (short, medium or long) can you start taking advantage of? \\
\hline 1.3. Which external actors can contribute to its development? \\
\hline 2. What aspects of our cultural heritage can we share to tourism? \\
\hline 2.1. What is needed (training, infrastructure, equipment) for its use? \\
\hline 2.2. In what period (short, medium or long) can you start taking advantage? \\
\hline 2.3. Which external actors can contribute to its development? \\
\hline 3. What tourist attractions have been used in our territory? \\
\hline 4. Which of the above is wanted and can be started in the short term and with less \\
\hline complication? (Hierarchy of resources with tourism potential) \\
\hline
\end{tabular}

\subsection{The role of researchers}

The research team prioritized acting as facilitators and companions for the diagnosis and detection of resources with potential for tourist attraction. In this diagnostic accompaniment, the resulting maps and diagrams consisted of simple schemes that allowed us to geographically understand the environment, natural resources with potential for tourism, as well as local traditions and aspects of the cultural heritage of the population.

The main interest was that, through touring the parts of the ejido territory, tourism resources could be identified one by one and for this, the support of the manual that was used as a guide in the course, was a material that was constantly consulted in the equipment during the mapping.

This contributed to the discussion and recognition of what exists within the territory and of the possible activities and sites with potential to be offered as part of nature tourism; and, in that way, enrich the offer of activities that extend the stay of visitors who are interested in the Grottoes. That is, generate alternatives to what is currently offered, which will allow a 
greater economic spill, in addition to being able to offer food and locally made products have an interested market, tourists.

\subsection{Enrichment and exchange of knowledge during participation}

During the participatory mapping activity, a greater dialogue, a space for knowledge sharing, was observed in the participants. At some moments in the mapping, the young people recognized they did not know part of the territory that the elders described with great security and a sense of appropriation.

On the contrary, the youth identified areas of difficult access, ravines and rocky areas where it was possible to offer rappelling and rock climbing; both are adventure tourism activities that tourists who prefer the challenge in nature increasingly demand. This interest was observed in young people and they expressed interest in being trained; while the aged, identified activities of lower risk and more contemplation, to offer tourism (Fig. 3).
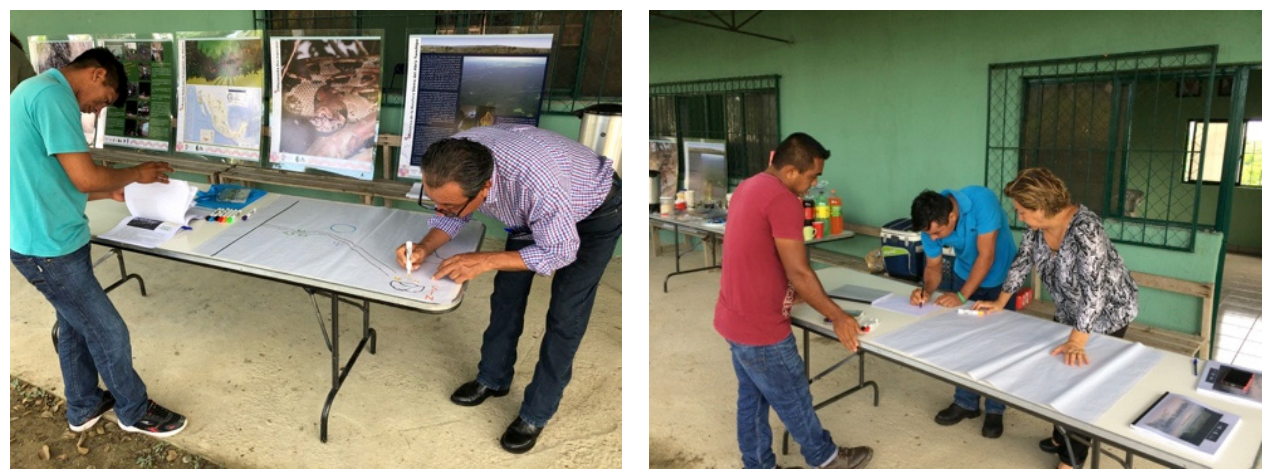

Figure 3: Identification of tourist attractions with participatory mapping.

\subsection{Consensus agenda of projects and actions to manage}

At the end of the presentation by each team, activities or sites with the possibility of being offered locally were listed. Those activities, sites and projects with greater feasibility of operating as part of the tourist offer that will complement the visit of the caves were prioritized.

Training and equipment needs, as well as identification of agents or support institutions for their development were listed and classified in the short, medium and long term.

The activities with the greatest interest in the short term were: (1) Establish an Environmental Management Unit (officially known as UMA) for the reproduction of native orchids for the purpose of environmental education, tourism and their trade, (2) Training in herbalism and elaborate products of the medicinal plants that can be used in the region, (3) Offer the traditional food and local cuisine to visitors, and, (4) To build a Bird watching tower by wood material and a zip line service over the Sotano del Arroyo (a natural abyss).

For this, training, equipment, support and financing needs were identified with respect to each service, product or project identified. It is then that, equally in a participatory manner, the governmental and non-governmental entities were identified to request the management of the same supports and the way they would be organized to carry out the management, assigning responsible in each identified need. 


\section{FINAL REMARKS}

Thanks to the methodology used, it is considered effective and democratic for the diagnosis of alternatives in the tourist offer, which complements the current limited offer. It is reflected that offering only the visit to the caves does not encourage greater efforts to participate in other activities by the ejido. By identifying numerous activities and sites with tourism potential, as well as projects to develop tourism products and services, it boosted the motivation of the participants, who were surprised about the various options that can be offered locally for tourism, in addition to the caves.

The participatory processes developed in this research allowed to facilitate the interpretation, assimilation and understanding of the mapped information, making it visible and tangible for all participants. An opening was identified among the participants for sharing knowledge. It could be perceived that through the participation in rural diagnoses, together with the training of the economic activity of interest, in this case, nature tourism, it is possible to motivate and create local awareness about the potential of their territories.

Thank to this experience, it can be shared with the academic community and field extensionists for rural development processes, which participatory mapping provides to the interested parties, powerful means for the efficient management of land use, ways to identify alternatives of economic activity, and which serves as an effective tool for community organization.

\section{ACKNOWLEDGEMENTS}

Thanks to the willingness and active participation of members from Ejido Los Sabinos Numero Dos, during the work days and great availability the subsequent visits by researchers. Thanks to the staff of the Comisión Nacional de Áreas Naturales Protegidas CONANP, who officially lead the management program of the RBSAT and for their support for this work.

\section{REFERENCES}

[1] SECTUR, DATATUR, Resultados de la actividad turística 2018. www.datatur.sectur.gob.mx/RAT/RAT-2018-01(ES).pdf.

[2] UNWTO World Tourism Barometer - Barómetro OMT del Turismo Mundial 2018. https://doi.org/10.18111/wtobarometeresp.2018.16.5.1.

[3] Secture, Programa Sectorial de Turismo, Plan estatal de desarrollo del gobierno del Estado de San Luis Potosí 2015-2021 2015. www.slp.gob.mx/programassectoriales2016-2021/assets/E1_4.pdf.

[4] Vázquez, J., Revisarán capacidad de carga de Pueblos Mágicos. El Economista, 11 Jul. 2018.

www.eleconomista.com.mx/estados/Revisaran-capacidad-de-carga-de-PueblosMagicos-20180611-0015.html.

[5] Bojórquez-Vargas, A.R., Hernández González, G. \& Suarez Rodríguez, I., Aprovechamiento Turístico en Cuevas. El caso del Ejido Los Sabinos, Huasteca Potosina. Turismo Espiritual II: Una visión Iberoamericana, ed. R. MartínezCárdenas, Universidad de Guadalajara: Guadalajara, Jalisco, pp. 151-161, 2013. www.eumed.net/libros-gratis/2013/1238/indice.htm.

[6] SEMARNAT, Programa De Manejo Reserva de la Biosfera Sierra del Abra Tanchipa. Secretaría de Medio Ambiente y Recursos Naturales: México, pp. 1-200, 2014. www.sierradelabratanchipa.org/pdfs/Programa de Manejo RBSAT.pdf. 
[7] SEMARNAT, Diario Oficial de la Federación, Norma Oficial Mexicana NOM-059SEMARNAT-2010, Protección ambiental-Especies nativas de México de flora y fauna silvestres-Categorías de riesgo y especificaciones para su inclusión, exclusión o cambio-Lista de especies en riesgo 30 Dec. 2010. www.gob.mx/cms/uploads/ attachment/file/134778/35.-_NORMA_OFICIAL_MEXICANA_NOM-059SEMARNAT-2010.pdf.

[8] United Nations Environment Programme, Division of Technology and Economics, Making tourism more sustainable: A guide for policy makers 2005. www.e-unwto.org/doi/pdf/10.18111/9789284408214.

[9] Chung-Shing, C., Yan Chiu, H. \& Marafa, L.M., The Mainland Chinese market for nature tourism in Hong Kong. Tourism Geographies, 19(5), pp. 801-822, 2017. https://doi.org/10.1080/14616688.2017.1360387.

[10] Wondirad, A., Who benefits from the ecotourism sector in Southern Ethiopia? International Journal of Tourism Sciences, 17(4), pp. 276-297, 2017. https://doi.org/10.1080/15980634.2017.1384133.

[11] Guillen, A., Sáenz, K., Badii, M.H. \& Castillo, J., Origin, space and levels of participation. International Journal of Good Conscience, 4(1), pp. 179-193, 2009. www.spentamexico.org/v4-n1/4(1)\%20179-193.pdf.

[12] Cadag, J.R.D. \& Gaillard, J.C., Integrating knowledge and actions in disaster risk reduction: The contribution of participatory mapping. Area, 44(1), pp. 100-109, 2012. https://doi.org/10.1111/j.1475-4762.2011.01065.x.

[13] Chapman, M. \& Kirk, K., Lessons for Community Capacity Building: A summary of the research evidence 2001. www.scothomes.gov.uk/pdfs/pubs/260.pdf.

[14] Aref, F., Sense of community and participation for tourism development. Life Science Journal, 8(1), pp. 20-25, 2011. www.lifesciencesite.com/lsj/life0801/03_4106life0801_20_25.pdf.

[15] Herawati, A., Purwaningsih, A., Pudianti, A. \& Surya, R.V., Rural tourism community empowerment based on local resources for improving community welfare: Case on Pentingsari village, Yogyakarta, Indonesia. Review of Integrative Business and Economics Research, 3(2), p. 88, 2014. www.sibresearch.org/uploads/2/7/9/9/2799227/riber b14-071 88-100.pdf.

[16] Osorio Campillo, H. \& Sánchez, E.R., La cartografía como medio investigativo y pedagógico. Dearq, 9, pp. 30-47, Dec. 2011. https://revistas.uniandes.edu.co/doi/pdf/10.18389/dearq9.2011.05.

[17] Perkins, C., Cartography: mapping theory. Progress in Human Geography, 27(3), pp. 341-351, 2003. https://doi.org/10.1191/0309132503ph430pr. 